\title{
Estimating Loss of the Wild-Type p53 Gene by In Situ Hybridization of Fine-Needle Aspirates from Breast Carcinomas
}

\author{
Torill Sauer, M.D., F.I.A.C., ${ }^{1 *}$ Kahsai Beraki, B.Sc., ${ }^{1}$ Irene Furu, C.T., ${ }^{1}$ \\ Eli Ormerod, B.Sc., ${ }^{2}$ Peter W. Jebsen, M.D., ${ }^{1}$ and Oddvar Næss, M.D. ${ }^{1}$
}

TP53 mutations have been found in 16-64\% of breast carcinomas. The aim of our study was to investigate loss of the wild-type TP53 gene by in situ hybridization (ISH) of fine-needle aspirates (FNAC) from breast carcinomas. The material consisted of FNAC from 33 breast carcinomas, with histologic specimens from 19 of the cases. Routine diagnostic smears were used for cytologic grading. ISH of the wild-type TP53 gene and chromosome 17 was performed on air-dried smears. Hybridization signals were counted in at least 100 nuclei, and the percentage for each signal number was calculated. FNAC from four fibroadenomas as well as cell preparations from five lymphocyte cultures were used as normal/benign controls. Cutoff for defining loss of p53 gene signals was set at $20 \%$ of cells with zero and one gene signal only. Concomitant p53 protein expression was determined on 20 histologic sections and eight additionally available air-dried smears.

Loss of wild-type p53 gene was found in 20 carcinomas $(60.6 \%)$. The rate of signal loss varied from $0.4 \%$ to $75.3 \%$ of the cells. All tumors with aneusomy of chromosome 17 revealed loss of 553 gene signals, as did $42 \%$ of the disome cases. Loss of wild-type 553 gene was present in 10 of 16 grade 1 cancers $(62.5 \%)$, eight of 13 grade 2 tumors (61.5\%), and two of four grade 3 cases. Signal loss did not correlate with 553 protein expression.

In conclusion, subpopulations with loss of the wild-type p53 gene are a common finding in breast carcinomas; they are detected in more than $60 \%$ of the tumors, including grade 1 cancers.

Diagn. Cytopathol. 1999;20:266-270. @ 1999 Wiley-Liss, Inc.

Key Words: p53; in situ hybridization; fine-needle aspirate; breast carcinoma; chromosome 17

Alterations in the p53 gene occur in about $60 \%$ of all human cancers. ${ }^{1,2}$ Commonly, one allele harbors a mutation that inactivates the normal function, and the second allele is lost

\footnotetext{
${ }^{1}$ Department of Pathology, Ullevaal University Hospital, Oslo, Norway ${ }^{2}$ Department of Medical Genetics, Ullevaal University Hospital, Oslo, Norway

Grant sponsor: Norwegian Cancer Society.

*Correspondence to: Torill Sauer, M.D., Department of Pathology, Ullevaal University Hospital, N-0407 Oslo, Norway. E-mail: sauer@ newmedia.no

Received 1 June 1998; Accepted 7 October 1998
}

through deletion or gene conversion, resulting in a loss of heterozygosity $(\mathrm{LOH})$ or a reduction to homozygosity in the tumor cells. ${ }^{3}$ The majority of the mutations are found in the domain that contains the sequence-specific DNA binding activity of the p53 protein, and they result in loss of DNA binding. ${ }^{4}$ More than $80 \%$ are missense point mutations and deletions that do not cause a downstream frameshift. Most alterations have been found in exons 5-8, and they are most often accompanied by p53 protein overexpression in the tumors. Mutations outside exons 5-8 are chiefly nonsense point mutations and deletions causing a downstream frameshift or stop codon, and these tumors are usually p53 protein negative. ${ }^{1,5,6}$

Wild-type p53 protein is a transcription factor that regulates entry into the $\mathrm{S}$-phase of the cell cycle and has the ability to induce apoptosis in malignant cells. ${ }^{3}$ Loss of these functions may result in genomic instability with accumulation of DNA damage, gene amplifications, and aneuploidy ${ }^{7}$ Tumor cells lacking normal p53 function thus have a selective growth advantage and might be expected to be more aggressive clinically than cells with normal p53 function.

Mutations in the p53 gene have been found in 16-64\% of breast carcinomas. ${ }^{8-16}$ The p53 gene is located at $17 \mathrm{p} 13 .{ }^{17}$ Structural abnormalities of chromosome 17 are common in breast cancer cells, ${ }^{18-22}$ reflecting alterations in the p53 and neu genes, among others. Numeric aberrations of chromosome 17 occur most often in high-grade, highly aneuploid tumors. ${ }^{23}$ Some studies have found that $\mathrm{LOH}$ at $17 \mathrm{p} 13.1$ correlates with p53 mutations, ${ }^{6,24}$ whereas others have not. ${ }^{9,25}$ Both overexpression of the p53 protein and alterations in the p53 gene have been associated with a worse prognosis in breast cancer. ${ }^{18,26-28}$

The aim of our study was to investigate the extent of loss of the wild-type p53 gene by in situ hybridization (ISH) of interphase cells on fine-needle aspirates (FNAC) from breast 
Table I. Procedure of In Situ Hybridization ${ }^{\mathrm{a}}$

1. Aspirates fixed in methanol/acetic acid (3:1) for $40 \mathrm{~min}$ at $-20^{\circ} \mathrm{C}$

2. Dehydration at room temperature (RT) in $70 \%, 80 \%$, and $96 \%$ alcohol, allowed to dry

3. Denaturation in $2 \times \mathrm{SSC}, 70 \%$ formamide at $\mathrm{pH} 7.0$ and $70^{\circ} \mathrm{C}$ for 2 $\min$

4. Dehydration at $-20^{\circ} \mathrm{C} ; 2$ min each in $70 \%, 80 \%$, and $96 \%$ alcohol; allowed to dry

5. Denaturation of $\alpha$-satellite probe (chromosome 17) $5 \mathrm{~min}$ in water bath at $70^{\circ} \mathrm{C}$

6. Pre-warming of $\mathrm{p} 53$ probe at $37^{\circ} \mathrm{C}$ for $5 \mathrm{~min}$

7. p53 gene and $\alpha$-satellite probes applied to separate areas of the slide and incubated at $37^{\circ} \mathrm{C}$ for $16 \mathrm{hr}$ (overnight)

8. Post-hybridization wash $(0.60 \times \mathrm{SSC}, \mathrm{pH} 7.0)$ at $72^{\circ} \mathrm{C}$ for $5 \mathrm{~min}$

9. Washed in PBS with $0.25 \%$ Triton-X 100 for 2 min at RT

10. Incubated with mouse anti-digoxigenin for $3 \mathrm{hr}$ at $\mathrm{RT}$

11. Incubated with biotinylated anti-mouse (ABC kit) for $30 \mathrm{~min}$ at RT

12. Washed with TBS, 5 min at RT

13. Incubated with $A B C$ complex for one hour at $\mathrm{RT}$

14. Washed with TBS, 5 min at RT

15. DAB solution $10 \mathrm{~min}$

16. Wash in running tap water, counterstain with hematoxylin and mount

aSSC, standard sodium citrate; PBS, phosphate-buffered saline; TBS, tris-buffered saline; ABC, avidin-biotin-complex; DAB, diaminobenzidine.

carcinomas. The results were correlated with overexpression of p53 protein, numeric abnormalities of chromosome 17, and cytologic grading.

\section{Materials and Methods}

The material consisted of fine-needle aspirates from 33 breast carcinomas and histologic paraffin-embedded material from 20 of the cases. Cytologic grading was performed according to the method of Robinson et al. ${ }^{29}$ on routine diagnostic smears. In cases where additional air-dried smears were available, they were put aside and kept at $-20^{\circ} \mathrm{C}$. ISH was performed according to the manufacturer's instructions, with the modifications shown in Table I. A digoxigeninlabeled $\alpha$-satellite probe for chromosome 17 (Oncor, Gaithersburg, MD) and a unique sequence probe (17p13.1) for detecting wild-type TP53 gene (Oncor, catalog no. p5106DG.5) were used. An ABC (avidin-biotin-complex) technique (Vector Laboratories, Burlingame, $\mathrm{CA}$ ) with diaminobenzidine (DAB) was used for visualization.

The number of signals for the p53 gene (Fig. 1) and chromosome 17 was counted in at least 100 well-preserved tumor cell nuclei. Only signals in clearly discernible nuclei were counted, and the percentage of cells with varying signal number was recorded. Smears from four fibroadenomas and five lymphocyte cell cultures were used as benign/ normal controls. For each of the benign specimens, the maximum and mean percentage of nuclei with none and one signal, respectively, of the p53 gene and chromosome 17 were assessed, to reveal the magnitude of insufficient hybridization. The sum of the maximum percentage of cells harboring zero and one signal of wild-type p53 gene in benign cells was used to define a cutoff of $20 \%$ for loss of

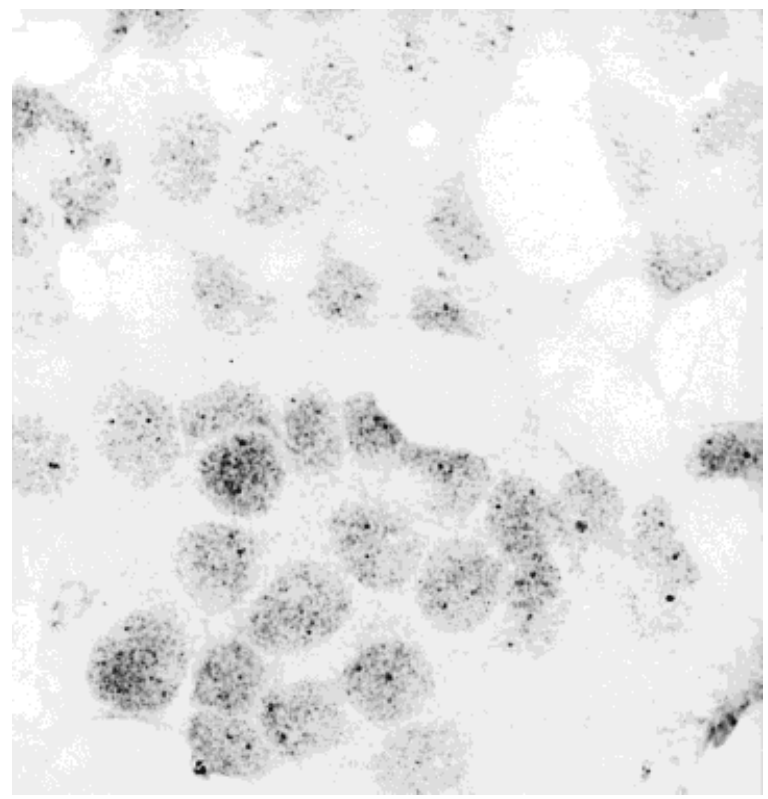

Fig. 1. Breast carcinoma cells without significant loss of wild-type p53 gene signals. Most nuclei harbor two small, dark (brown) signals $(\times 1,000)$.

p53 gene signals in the carcinoma cells. Whenever there was extensive numeric gain of chromosome 17, the ratio between 553 gene and chromosome 17 signal numbers was estimated, to reveal the relative loss of wild-type p53 gene signals. The p53 hybridization signals were significantly smaller than the centromere signals and had to be counted under oil immersion $(\times 100)$. We applied a stringent posthybridization wash with $0.6 \times \mathrm{SSC}$ instead of $0.2 \times \mathrm{SSC}$ (standard sodium citrate), as proposed from Oncor for p53 determination. In chromosome 17, the rate of insufficient hybridization was used only as a quality control. We corrected for this rate when determining whether a tumor had a normal or abnormal number of chromosome 17 . Specimens with $\geq 70 \%$ two-signal nuclei were regarded as disome for chromosome 17. Both loss and gain of chromosome numbers outside this range were regarded as aneusomy. ${ }^{23}$ In general, counting of both the centromere and the gene signals takes approximately $15 \mathrm{~min}$.

Concomitant $\mathrm{p} 53$ protein expression could be evaluated in 28 of the 33 cases. Twenty histologic specimens and eight air-dried smears were analyzed using a monoclonal antibody for p53 from Ventana (Ventana Medical Systems, Inc., Finland; catalog no. 250-1542), prediluted and with microwave pretreatment. Staining was performed on the Ventana ES automated immunostaining system. A biotinylated secondary antibody and avidin-horseradish peroxidase with DAB werre used for visualization. Staining for $\mathrm{p} 53$ protein was considered positive when $>10 \%$ of tumor cell nuclei were positive. A known p53 protein-positive breast carcinoma was used as control. 
Table II. Estimates on Insufficient Hybridization of Wild-type p53 Gene in Fibroadenoma Cells and Lymphocytes

\begin{tabular}{lcc}
\hline Percentage of p53 gene signals & $\begin{array}{c}\text { Lymphocyte } \\
\text { preparations }\end{array}$ & $\begin{array}{c}\text { Fibroadenoma } \\
\text { cells }\end{array}$ \\
\hline Maximum of zero signals & $11 \%$ & $8.6 \%$ \\
Mean of zero signals & $5.1 \%$ & $7.7 \%$ \\
Maximum of one signal & $12.4 \%$ & $11.1 \%$ \\
Mean of one signal & $7.6 \%$ & $8.5 \%$ \\
Maximum of zero plus one signal & $20.9 \%$ & $18.8 \%$ \\
Mean of zero plus one signal & $12.7 \%$ & $16.2 \%$ \\
\hline
\end{tabular}

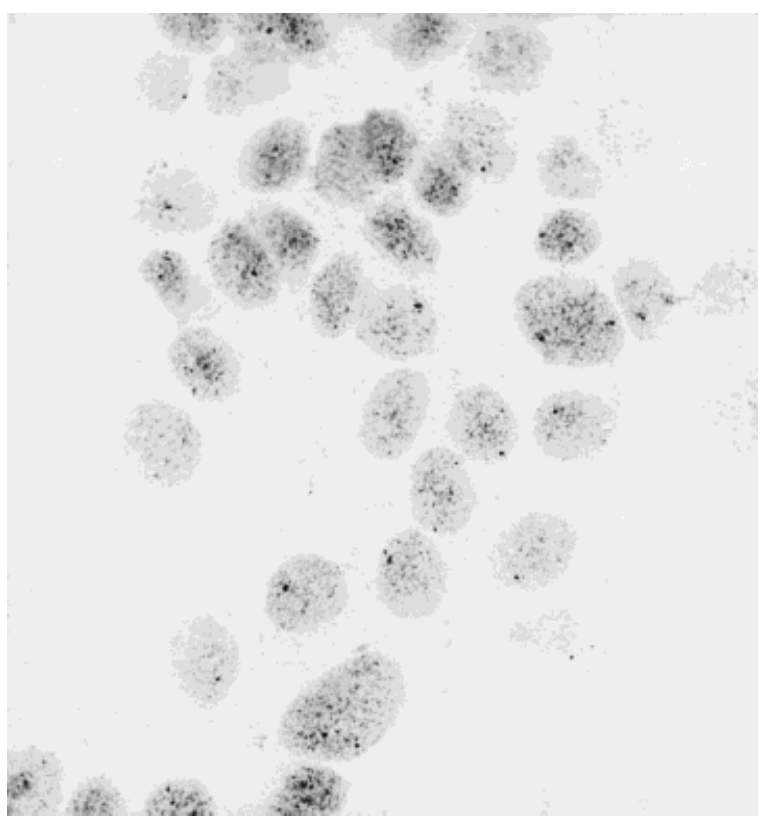

Fig. 2. Breast carcinoma cells with significant loss of wild-type p53 gene signals. Many nuclei harbor only one gene signal. Some nuclei have no p53 gene signal, whereas some tumor cells have kept both wild-type signals $(\times 1,000)$.

\section{Results}

The maximum and mean percentages of fibroadenoma cells and lymphocytes showing only one or zero wild-type p53 gene signals are shown in Table II. The largest percentage of cells with one plus zero gene signal was 20.9\%; this percentage was found in one of the lymphocyte preparations. According to these figures, $20 \%$ of cells showing loss of gene signals was chosen as the cutoff for defining loss of the wild-type p53 gene on the carcinoma specimens. ISH revealed aneusomy of chromosome 17 in nine cases $(27 \%)$. Three of these showed hyposomy with signal loss $(80 \%$, $40 \%$, and $28 \%$ monosomy, respectively), whereas six had signal gain. Loss of wild-type p53 gene signals (Fig. 2) was found in 20 of 33 carcinomas $(60.6 \%)$. In two of these 20 , the percentage of signal loss was proportional to the loss of chromosome signals (the cases with $80 \%$ and $40 \%$ monosomy of chromosome 17). Two cases with extensive gain of chromosome 17 signals had a relative loss of p53 gene signals.
Table III. Relationship of Numerical Aberrations of Chromosome 17, Cytologic Grading, Immunohistochemical Determination of p53 Protein and Loss of Wild-type p53 Gene Signals

\begin{tabular}{lcc}
\hline & $\begin{array}{c}\text { Loss of p53 gene } \\
\text { signals }\end{array}$ & $\begin{array}{c}\text { No loss of p53 gene } \\
\text { signals }\end{array}$ \\
\hline Aneusomy chrom 17 & 9 & \\
Disomy chrom 17 & 11 & 13 \\
Grade 1 & 10 & 6 \\
Grade 2 & 8 & 5 \\
Grade 3 & 2 & 2 \\
P53 protein positive & 6 & 9 \\
P53 protein negative & 11 & 2 \\
\hline
\end{tabular}

Table IV. Comparison of Loss of Wild-type p53 Gene Signals and Cytologic Grading in Breast Carcinomas with Disomy of Chromosome 17

\begin{tabular}{lcc}
\hline Cytologic grading & Loss of p53 gene signals & No loss of p53 gene signals \\
\hline 1 & 7 & 6 \\
2 & 3 & 5 \\
3 & 1 & 2 \\
\hline
\end{tabular}

Loss of wild-type p53 gene signals varied from $0.4 \%$ to $75.3 \%$, with a mean of $22.5 \%$ and a median of $14 \%$. Significant loss of both gene signals was found in six cases. A mixed loss was shown in eight specimens, whereas six tumors mainly had loss of one gene signal. Grade 1 tumors had a mean loss of $23.9 \%$, a median of $14 \%$, and a maximum of $75.3 \%$. Grade 2 cancers showed a mean loss of $20.1 \%$, a median of $8.4 \%$, and a maximum of $58 \%$. The relationships between p53 gene loss/no loss and numeric aberrations of chromosome 17, cytologic grading, and immunohistochemically determined p53 protein are shown in Table III. Chromosome 17 disomy was found in 13 of 16 grade 1 tumors, eight of 13 grade 2 tumors, and three of four grade 3 cancers. Characteristics of p53 gene signal loss and grading in tumors with disomy of chromosome 17 are shown in Table IV.

\section{Discussion}

Determination of the loss of the wild-type p53 gene provides an indirect estimate of p53 mutations and deletions, but without any specifications as to type of abnormality. Our results yielded a rather high rate of loss of wild-type p53 $(60.6 \%)$. They are in concordance with the results of Deng et al., ${ }^{9}$ who found p53 mutations in $57 \%$ of breast cancers, and with those of Singh et al., ${ }^{12}$ who found $64 \%$ loss of the p53 allele. A number of studies with lower percentages $8,10,13,15,16$ have mainly screened for mutations in exons 5-8, which may underestimate the mutation rate by approximately $20 \% .^{5}$

On the basis of the results from the controls, we defined a cutoff of $20 \%$ signal loss to correct for insufficient hybridization. This is the same level as set by Li et al. ${ }^{30}$ whereas two other studies defined the cutoff at $40 \%$ and $50 \%$, respectively. ${ }^{31,32}$ They both used FISH and had a somewhat higher rate of insufficient hybridization. In contrast to $\mathrm{FISH}$, 
nonfluorescent ISH does not give a cell-to-cell relationship between the p53 gene and chromosome 17 signal number but rather the rate of carcinoma cells lacking wild-type p53 within the individual tumors.

Subpopulations with loss of wild-type p53 are apparently common, even in low-grade tumors. The extent of loss was highly variable in both grades 1 and 2 carcinomas, but the mean loss and median loss were about the same in both groups. Most cases revealed a moderate loss of the wild-type p53 gene, with approximately $20 \%$ of tumor cells showing signal loss. The highest rate was found in a grade 1 cancer with $75 \%$ signal loss, mostly of both alleles, whereas there was disomy of chromosome 17.

All tumors with aneusomy of chromosome 17 revealed loss of the wild-type p53 gene. This finding is consistent with previous findings that aneusomy of chromosome 17 is a feature of malignancies with extensive chromosomal abnormalities. ${ }^{23}$ In addition, $42 \%$ of carcinomas with disomy of chromosome 17 showed loss of wild-type p53 gene. The same pattern was observed by Matsyama et al. ${ }^{33}$ in a study on urothelial tumors. According to Yin et al., ${ }^{34}$ wild-type p53 restores cell cycle control in vitro in cells with mutant p53 alleles. It is possible, therefore, that tumor cells lacking only one wild-type allele maintain a normal cell cycle control, whereas this control will be lost in cancer cells lacking both wild-type alleles. A dominant loss of both gene signals or a mixed loss was found in 14 of our cases (seven grade 1, five grade 2 , and two grade 3 ).

Fifty-three percent of the immunocytochemically analyzed tumors revealed overexpression of p53 protein. In $60 \%$ of these tumors, however, no loss of the wild-type p53 gene was found. Conversely, $65 \%$ of carcinomas harboring loss of wild-type p53 were negative for the p53 protein. Thorlacius et al. ${ }^{28}$ found that $58 \%$ of $\mathrm{p} 53$-protein-positive cases did not harbor p53 missense mutations, whereas Singh et al. ${ }^{12}$ detected protein-positive results in $50 \%$ of the p53 mutants. Other researchers have found a somewhat lower figure, with about $30 \%$ discrepancies between p53 mutations/no mutations and $\mathrm{p} 53$ protein status. ${ }^{13,16}$

Possibly, our results are better compared with $\mathrm{LOH}$ at $17 \mathrm{p} 13$. Tsuda et al. ${ }^{6}$ ascertained that $83 \%$ of tumors with p53 mutations revealed LOH at $17 \mathrm{p} 13$. In their study, Singh et al. ${ }^{12}$ found no correlation between $\mathrm{p} 53$ protein overexpression and $\mathrm{LOH}$ at 17.13. Several factors might influence discrepancies between immunocytochemically determined p53 protein expression and p53 gene abnormalities. Most important is probably the rate of nonsense mutations and deletions that do not result in an abnormal p53 protein, which may account for approximately $20 \%$ of the aberrations. ${ }^{1,5}$ In addition, specimen-fixation artifacts, different epitope specificity of antibodies, and aberrant overexpression of wild-type protein may contribute to divergence in the results.
In conclusion, subpopulations with loss of the wild-type p53 gene are a common finding in breast carcinomas; they are seen in more than $60 \%$ of these tumors, including grade 1 tumors. Preoperative investigation of this feature might have a role in singling out tumors with possibly more aggressive behavior and aid in deciding on the optimal primary treatment of the patients.

\section{References}

1. Levine AJ, Perry ME, Chang A, et al. The 1993 Walter Hubert lecture: the role of the p53 tumour-suppressor gene in tumorigenesis. $\mathrm{Br} \mathrm{J}$ Cancer 1994;69:409-416.

2. Hollstein M, Sidransky D, Vogelstein B, Harris CC. P53 mutations in human cancers. Science 1991;253:49-53.

3. Levine AJ, Momand J, Finlay CA. The p53 tumour-suppressor gene. Nature 1991;351:543-546.

4. Cho Y, Gorina S, Jeffrey PD, Pavletich NP. Crystal structure of a p53 tumor suppressor-DNA complex: understanding tumorigenic mutations. Science 1994;265:346-355.

5. Greenblatt MS, Bennett WP, Hollstein M, Harris CC. Mutations in the p53 tumor suppressor gene: clues to cancer etiology and molecular pathogenesis. Cancer Res 1994;54:4855-4878.

6. Tsuda H, Hirohashi S. Association among p53 gene mutation, nuclear accumulation of the $\mathrm{p} 53$ protein and aggressive phenotypes in breast cancer. Int J Cancer 1994;57:498-503.

7. Livingstone LR, White A, Sprouse J, Livanos E, Jacks T, Tisty TD. Altered cell cycle arrest and gene amplification potential accompany loss of wild-type p53. Cell 1992;70:923-935.

8. Andersen TI, Holm R, Nesland JM, Heimdal KR, Ottestad L, Børresen A-L. Prognostic significance of Tp53 alterations in breast carcinoma. Br J Cancer 1993;68:540-548.

9. Deng G, Chen L-C, Schott DR, et al. Loss of heterozygocity and p53 gene mutations in breast cancer. Cancer Res 1994;54:499-505.

10. Eyfjord J, Thorlacius S, Steinarsdottir M, Valgardsdottir R, Øgmundsdottir HM, Anamthawat-Jonsson K. P53 abnormalities and genomic instability in primary breast carcinomas. Cancer Res 1995;55:646-651.

11. Hurlimann J, Chaubert P, Benhattar J. P53 gene alterations and p53 protein accumulation in infiltrating ductal breast carcinomas: correlation between immunohistochemical and molecular biology techniques. Mod Pathol 1994;7(4):423-428.

12. Singh S, Simon M, Meybohm I, et al. Human breast cancer: frequent p53 allele loss and protein overexpression. Hum Genet 1993;90:635640.

13. Sjøgren S, Inganas M, Norberg T, et al. The p53 gene in breast cancer: prognostic value of complementary DNA sequencing versus immunohistochemistry. J Natl Cancer Inst 1996;88(3/4):173-181.

14. Gretarsdottir S, Tryggvadottir L, Jonasson JG, et al. TP53 mutation analyses on breast carcinomas: a study of paraffin-embedded archival material. Br J Cancer 1996;74:555-561.

15. Valgardsdottir R, Tryggvadottir L, Steinarsdottir M, et al. Genomic instability and poor prognosis associated with abnormal TP53 in breast carcinomas: molecular and immunohistochemical analysis. APMIS 1997;105:121-130.

16. Visscher DW, Sarkar FH, Shimoyama RK, Crissman JD. Correlation between p53 immunostaining patterns and gene sequence mutations in breast carcinoma. Diagn Mol Pathol 1996;5(3):187-193.

17. Leong AS-Y, Lee AKC. Biological indices in the assessment of breast cancer. J Clin Pathol 1995; 48:M221-M238.

18. Andersen TI, Gaustad A, Ottestad L, et al. Genetic alterations of the tumor suppressor gene regions $3 p, 11 p, 13 q, 17 q$ and $17 p$ in human breast carcinomas. Genes Chromosom Cancer 1992;4:113-121.

19. Bieche I, Lidereau R. Genetic alterations in breast cancer. Genes Chromosom Cancer 1995;14:227-251.

20. Matsumura K, Kallioniemi A, Kallioniemi O-P, et al. Deletion of chromosome $17 \mathrm{p}$ loci in breast cancer cells detected by in situ hybridization. Cancer Res 1992;52:3474-3477. 


\section{SAUER ET AL.}

21. Pandis N, Jin Y, Gorunova L, et al. Chromosome analysis of 97 primary breast carcinomas: identification of eight karyotypic subgroups. Genes Chromosom Cancer 1995;12:173-185.

22. Watatani M, Nagayama K, Imanishi Y, et al. Genetic alterations on chromosome 17 in human breast cancer: relationships to clinical features and DNA ploidy. Breast Cancer Res Treat 1993;28(3):231239.

23. Sauer T, Beraki K, Jebsen PW, Ormerod E, Næss O. Ploidy analysis by in situ hybridization of interphase cell nuclei in fine-needle aspirates from breast carcinomas: correlation with cytologic grading. Diagn Cytopathol 1997;17(4):267-271.

24. Cornelis RS, van Vliet M, Vos CBJ, et al. Evidence for a gene on 17.p13.3, distal to TP53, as a target for allele loss in breast tumors without p53 mutations. Cancer Res 1994;54:4200-4206.

25. Thompson AM, Andreson TJ, Condie A, et al. P53 allele losses, mutations and expression in breast cancer and their relationship to clinico-pathological parameters. Int J Cancer 1992;50:528-532.

26. Børresen A-L, Andersen TI, Eyfjord JE, et al. TP53 mutations and breast cancer prognosis: particularly poor survival rates for cases with mutations in the zinc-binding domains. Genes Chromosom Cancer 1995;14:71-75.

27. Kovach JS, Hartmann A, Blaszyk H, Cunningham J, Schaid D, Sommer SS. Mutations detection by highly sensitive methods indicates that $\mathrm{p} 53$ gene mutations in breast cancer can have important prognostic value. Proc Natl Acad Sci U S A 1996;93:1093-1096.
28. Thorlacius S, Thorgilsson B, Bjørnsson J, et al. TP53 mutations and abnormal p53 protein staining in breast carcinomas related to prognosis. Eur J Cancer 1995;31A(11):1856-1861.

29. Robinson IA, McKee G, Nicholsen A, et al. Prognostic value of cytologic grading of fine-needle aspirates from breast carcinomas. Lancet 1994;343:947-949.

30. Li X, Tsuji T, Wen S, Mimura Y, Sasaki K, Shinozaki F. Detection of numeric abnormalites of chromosome 17 and p53 deletions by fluorescence in situ hybridization in pleomorphic adenomas and carcinomas in pleomorphic adenoma. Cancer 1997;79(12):2314-2319.

31. Kobayashi M, Kawashima A, Mai M, Ooi A. Analysis of chromosome 17 p13 (p53 locus) alterations in gastric carcinoma cells by dual-color fluorescence in situ hybridization. Am J Pathol 1996;149(5):15751584.

32. Sauter G, Deng G, Moch H, et al. Physical deletion of the p53 gene in bladder cancer: detection by fluorescence in situ hybridization. Am J Pathol 1994;144(4):756-766.

33. Matsyama H, Pan Y, Mahdy EA, et al. P53 deletion as a genetic marker in urothelial tumor by fluorescence in situ hybridization. Cancer Res 1994;54:6057-6060.

34. Yin Y, Tainsky MA, Bischoff FZ, Strong LC, Wahl GM. Wild-type p53 restores cell cycle control and inhibits gene amplification in cells with mutant p53 alleles. Cell 1992;70:937-948. 